\title{
Characteristics of Geological Nature of Inverted Ring Structures in the Limited Area of the Arctic Regions of the West Siberia as a Criterion of Petroleum Potential
}

\author{
Arkadiy Kurchikov ${ }^{1}$, Vladimir Borodkin ${ }^{1}$, Andrey Lukashov ${ }^{2}$, Anton Nedosekin ${ }^{2}$, Oleg Smirnov $^{2}$ \\ ${ }^{1}$ Faculty of Oil and Gas Field, Tyumen Industrial University, Tyumen, Russia \\ ${ }^{2}$ Ingeoservice Llc, Tyumen, Russia
}

Email address:

osmirnov@ingeos.info (O. Smirnov)

To cite this article:

Arkadiy Kurchikov, Vladimir Borodkin, Andrey Lukashov, Anton Nedosekin, Oleg Smirnov. Characteristics of Geological Nature of Inverted Ring Structures in the Limited Area of the Arctic Regions of the West Siberia as a Criterion of Petroleum Potential. American Journal of Environmental Science and Engineering. Vol. 3, No. 3, 2019, pp. 52-59. doi: 10.11648/j.ajese.20190303.12

Received: April 2, 2019; Accepted: May 28, 2019; Published: October 28, 2019

\begin{abstract}
The subject of study and research of seismic artifacts, which include the study of abnormal seismic records is related to the history of tectonic development, fluid dynamic processes in the sedimentary cover interval, distribution of the thermobaric effects from formation fluid flow, upflow hydrocarbon migration and other features of the evolution of the Earth's crust. On the territory of Western Siberia and the Kara Sea basin there is a wide development of abnormal forms of seismic record in the form of abnormal ring structures (ARS), also called inverted ring structures (IRS), fluid dynamic abnormities (FDA). ARS are vertically extended ringshape of wave field deformation. The most complete study of the identified ARS by 3D seismic data. A lot of statistics data of such kind of abnormal antiforms accumulated at the present time. There are still many questions about cause and effect relationship of such artifacts with the secondary hydrocarbons migration mechanism, formation and accumulation hydrocarbon deposits, impact on vertical and lateral hydrocarbon migration intensity, the abnormal high pore pressures occurrence. One of the trends of seismic interpretation is studying of fluid dynamic abnormalities of seismic record and the relation with oil and gas potential in the sedimentary basin. In the article, the attempt is to establish to identify the correlation between various forms of fluid dynamic structures (FDS) with time and the stages of deep formation fluids migration occurrence. It is possible that the allocation of new types of hydrocarbon deposits of fluid dynamic type may be associated with ARS. It is still a hypothesis. But the presence and analysis of seismic attributes allow us to make this suggestion. What is positive is that all ARS studied by drilling related to the multi-bedded deposits. Identification and studying ARS patterns of relations with the mechanism of formation and accumulation hydrocarbon deposits allow us to conduct exploration geological prospecting works more efficiently, estimate correctly geological risks, rank and identify the most prospecting areas for exploratory drilling. The practice of prospecting of recent years has shown the accuracy and informatively of this trend as an indicator of petroleum potential.
\end{abstract}

Keywords: Bolshekhetskaya Depression, The Kara Sea Shelf, IRS, The Abnormal High Pore Pressure (AHPP), Gravity - Magnetic and Velocity Anomalies

\section{Introduction}

Various aspects of oil and gas bearing local prognosis had been considered in the previous work [1] where the inverted ring structures (IRS) were presented among the other criteria as one of the estimation indicators of the oil and gas potential.

The largest number of IRS was found in the Bolshekhetskaya Depression (Yanguskaya, North-Khalmerpayutinskaya,
Khalmerpayutinskaya, Pyakyakhinskaya, Nakhodka, etc.), UstYeniseysky District (Pelyatkinskaya, Nanedeyakhskaya, Kuban, etc.), as well as in the offshore part of the Kara Sea (Rusanovskaya, Petrovskaya, etc.) (Figure 1), the authors had carried out the studies earlier [2-3]. IRS are uplifted local rings along the Neocomian horizons, turning into depressions along the Jurassic horizons.

There are several points of view that are based on the processes of deep Earth degassing, the large hydrocarbon 
potential floor, the destruction zone existence, the abnormal high pore pressure (AHPP), avalanche sediment processes at the edge of Jurassic and early Neocomian periods, etc. ([4-8, etc.]). At the same time, they all remain just hypotheses because a seismic section interval that we are interested in (Clinform Neokom, Jurassic sediments) is virgin/undrilled as in the Kara Sea shelf, so in the Bolshekhetskaya depression. The nearest to the Bolshekhetskaya Depression IRS, studied by drilling, is the Yamburg Uplift (Figure 2).

Achimov strata anomalous thicknesses (more than $200 \mathrm{~m}$ ) are typical for it. Where six hydrocarbon reservoirs (HC) with
AHPP were identified there, also the reserves were estimated in the group layers PK (Cenomanian), BU (Neocomian) and Tyumen suites $\left(\mathrm{U}_{2-4}\right)$, i.e. the large hydrocarbon potential floor. At the same time, the AHPP is set only in the lower part of the section that had been explored by drilling (middle Jurassic, Clinform Neokomian) having the separated collectors that is one of criteria to form AHPP [9].

Regardless of how the nature of IRS is perceived, such geological objects at this stage of exploration can be considered as an additional criterion of the prospect studied territory.

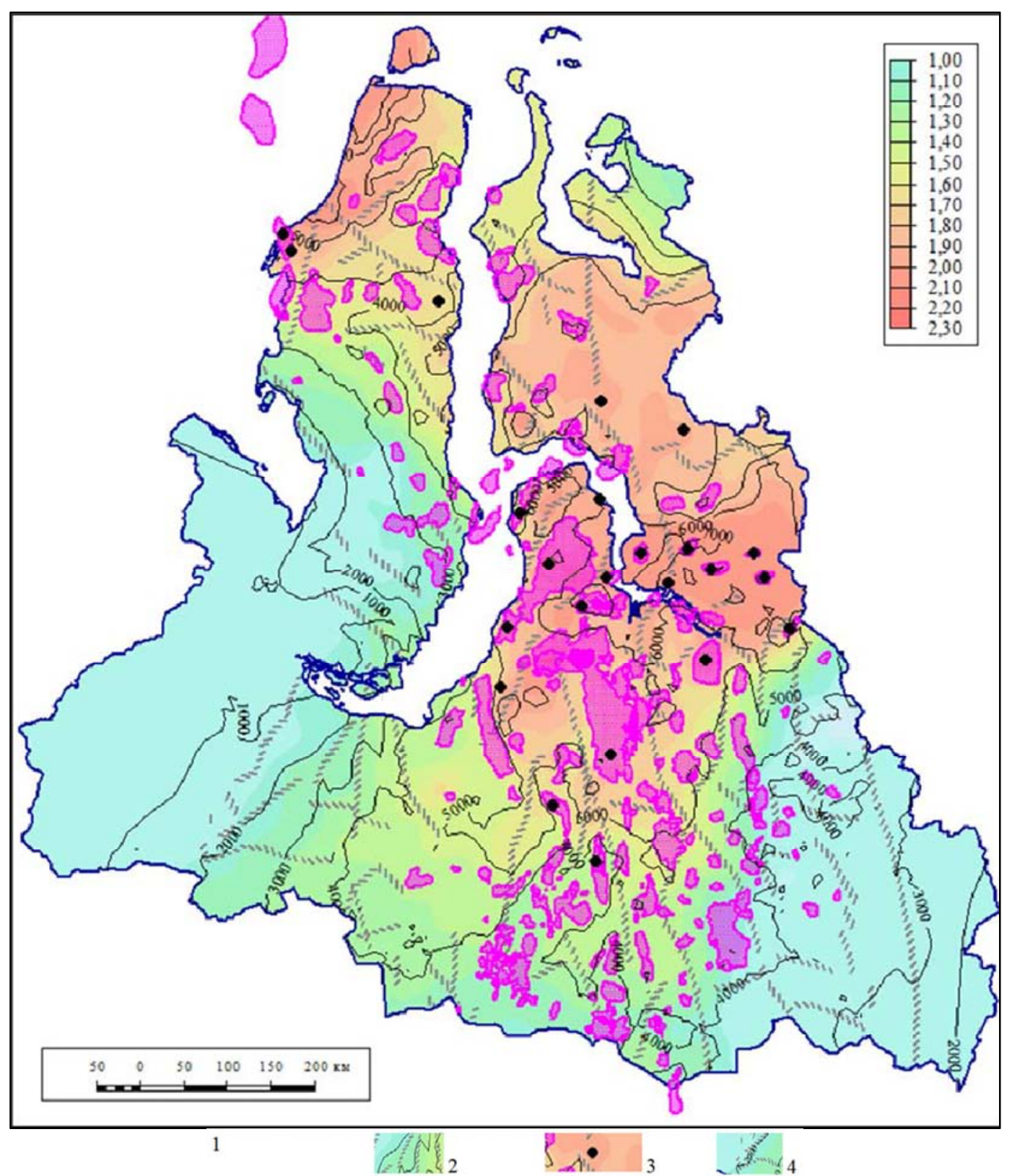

Figure 1. Regional map of the anomaly coefficient of the upper part of the Tyumen suite deposits (beds $Y u_{2}-Y u_{3}$ ) with imposed A depth map.

1. Inversion ring structures with a system of rifts and boundaries of known hydrocarbons fields from the northern and arctic regions of Western Siberia (Zagorovsky Yu. A., 2013);

2. Identified fields boundaries in the section of the Mesozoic;

3. Rifts;

4. Depth map of reflected horizon A, $\mathrm{m}$. 

Area of the Arctic Regions of the West Siberia as a Criterion of Petroleum Potential

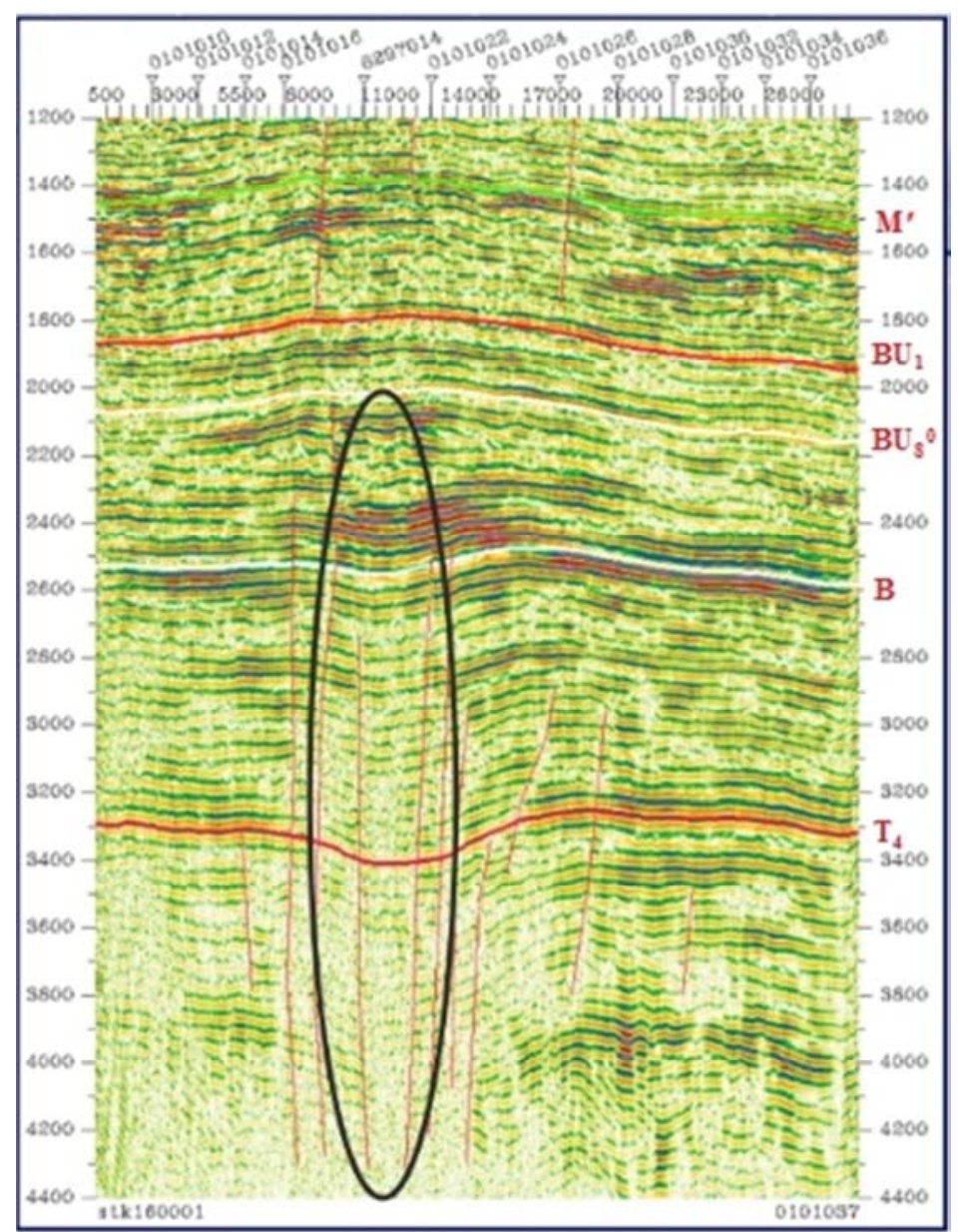

Figure 2. Inversion ring structure within the Yamburg Uplift.
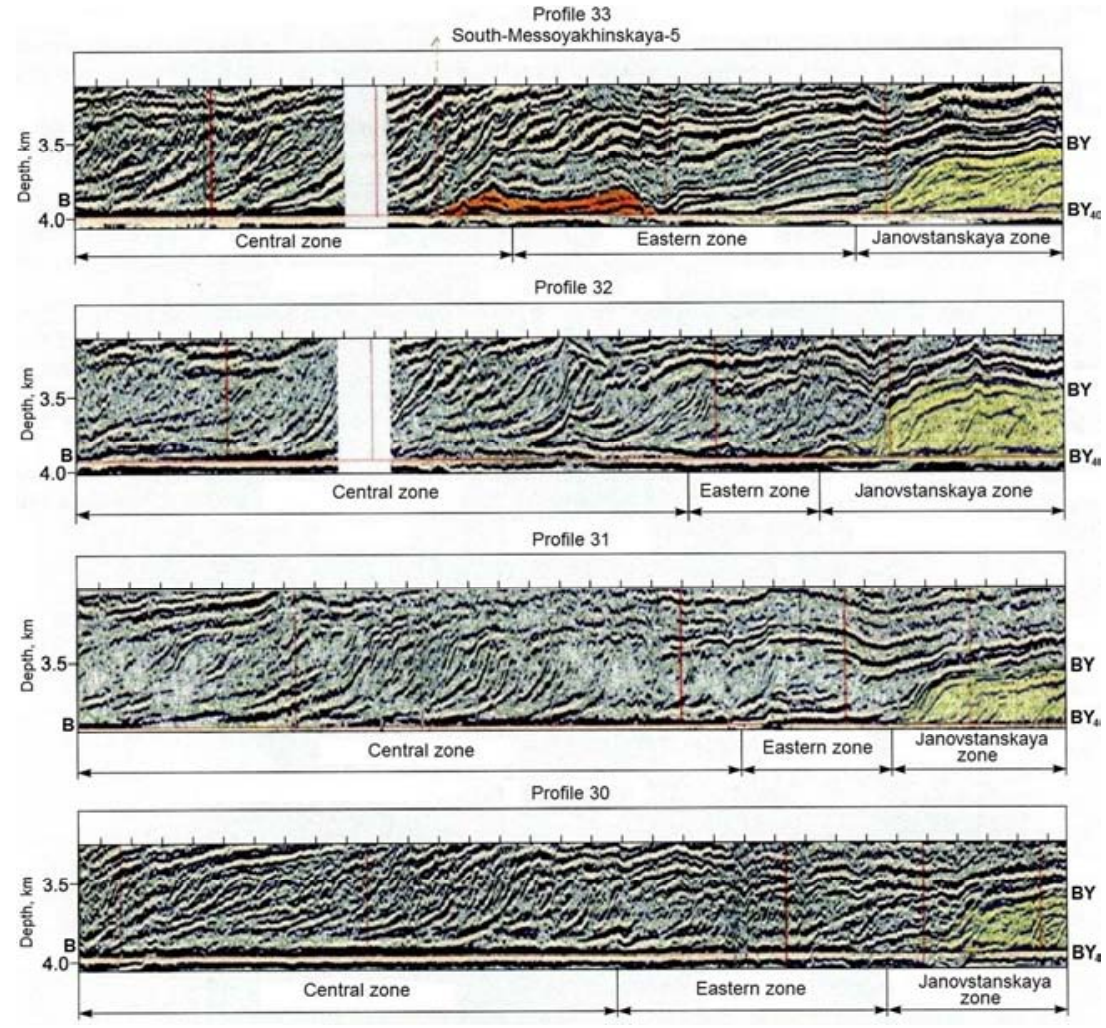

Figure 3. Clinoform seismic geological model of the boundary of the Janovanskaya suite and the Achimov strata of the Bolshekhetskaya Depression. 


\section{Characteristics of the Geological Nature of the IRS}

Until recently, there were no any deep wells that were drilled within the Bolshekhetskaya Depression to discover Jurassic sediments.

According to the results of seismic survey in the zone (eastern part) that reflects the horizon B is not traced while its analogue is considered to be the seismic horizon $\mathrm{BY}_{40}$. It mapped above the Sigov suite. Sigmoid reflections are identified above the horizon $\mathrm{BY}_{40}$ with clinoform construction (Figure 3) [10-11, etc.].

Due to the lack of well data and the fact that these reflections in section lie above the horizon $\mathrm{BY}_{40}$, many researchers were more likely to classify them as clinoform of the Achimov strata.

When choosing the location of the first deep well within the Bolshekhetskaya depression (the well Halmernayutinskaya - 2099) the possibility of development the Achimov strata in the sandy-aleuritic facies took into account, the strata is productive and located in the south of the East-Urengoy zone, on Yamburg and Olikuminsky uplifts, as well as the presence of the IRS.

Drilling the deep wells as the Tukolando-Vadinskaya - 320 zone, Pyakyakhinskaya -2011 and Khalmerpayutinskaya 2099 in this area showed (macro and microfauna age definition) that the clinoforms which had been selected by the "Reapak RD" method (Figure 4) associated with the Janovstan suite of the late Kimmeridgian - early Berriasian age and referred to a clayey section [10].

The field description of the core in the Khalmerpayutinskoe well - 2099 was performed in all intervals characterizing the lowest horizons of the Cretaceous and most part of the upper Jurassic sedimentary formations (depth interval from 3643 to $4227 \mathrm{~m}$ ).

Lithological features, faunal findings [10] clearly prove the upper Jurassic age of the clinoform section. The dark color rocks dominates from the Berriasian part of the Janovstan suites down by the section.

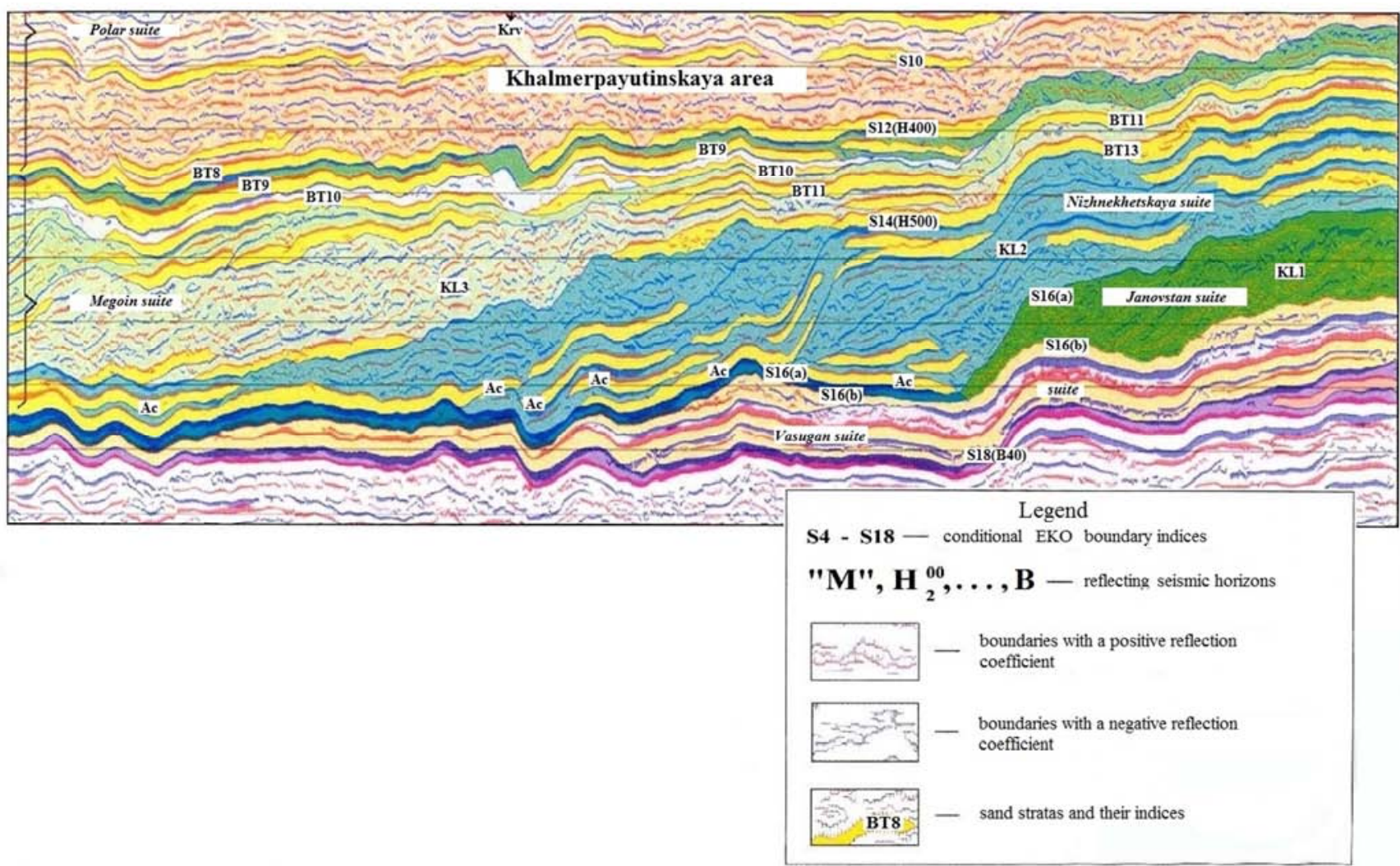

Figure 4. Seismic section by regional line XXXII.

Signs of hydrocarbons are being observed almost throughout the entire section of the upper Jurassic sedimentary formations (including claystones) as follows: the odor in a fresh cleavage and small oil saturated lenses of sandy-aleuritic rocks. Inclusions and diffuse pyrite are found throughout the whole interval of core selection, the presence of rock fracture.

Based on a correlation scheme of the following wells: Khalmerpayutinskoy - 2099, Tukolando-Vadinskaya - 320 and Russko-Rechenskaya - 720 [10], the intense gas showings that were observed in the well - 2099 with a bottom hole of $4302 \mathrm{~m}$ (anomaly coefficient - 2.0) are associated with the top of the Malyshevskaya suite.

For the prognosis evaluation of the undrilled Jurassic section the characteristic of the IRS of the Bolshekhetskaya depression in the gravity anomalies is presented (Figure 5), which shows their conformation in the negative anomalies $\Delta \mathrm{g}$. The IRS are not displayed in the magnetic field, 
although, according to V.Kashtanov [12], the US fields are directly related to magnetic anomalies.

They are caused by the presence in the overlying strata of secondary magnetite, which is formed as a result of reduction chemical reactions with the presence of hydrocarbon gases. An increasing rock magnetism above the oil and gas reservoirs is also typical for the territory of Western Siberia, due to the development of magnetite iron, titano-magnetite, siderite [12]. If we focus mainly on the position of geodynamic processes of hydrocarbon formation, this is explained by the presence of frequent changes of redox conditions because of the massive $\mathrm{HC}$ permeability through sedimentary strata in the fluid-migration zones. The nonmagnetic pyrite presence in the subvertical zones apart from the magnetic minerals can be explained by chemical reactions of sulfur and iron compounds as a result of hydrocarbon penetration. [13].Sulfur in sulfide minerals was formed from two sources: from oil and as a result of the activity of sulfate-reducing bacteria. In a vertical hydrocarbons migration zones minerals with magnetic properties can appear, that are determined both chemically and biologically. These include various oxides of iron and sulfurous iron, for example, greychite and diagenetic magnetite $\left(\mathrm{Fe}_{3} \mathrm{O}_{4}\right)$, which are usually considered as sources of magnetic anomalies above the oil fields. Even nonmagnetic pyrite minerals can greatly affect the magnetization of rocks. For example, the process of pyritization when replacing clastic magnetic oxides of iron can significantly reduce the level of magnetization.
As mentioned above, in the well 2099 both in the core and in the sludge were a high pyrite content. Sulfides with magnetic properties are the product of sulfate reduction by bacteria, which receive their energy from organic matter $(\mathrm{OM})$ [14]. The specific geochemical situation over hydrocarbon fields depends on the ratio of hydrocarbons flow speed and the intensity of their oxidation. The oils themselves are diamagnetic. However, under reservoir conditions, they sometimes acquire paramagnetic properties [15] it is caused by the association of iron and its oxides with the organic components of the fluid system, as well as the changing concentration of these compounds in the fluidmigration zones [16].

Often the subvertical fracturing of fluid-migration zones is recorded by increasing magnetization and present the injection areas (AHPP zones). At the same time, it is appropriate to note the data availability [17] of the existence the vertical rock demagnetization columns above oil reservoirs in oil and gas regions (due to the reduction of oxidative forms of iron). It seems that this situation found above the IRS in the Bolshekhetskaya Depression.

According to the nature of seismic recording in the IRS zone there are negative anomalies $\Delta \mathrm{g}$ (Figure 5), significant rocks fracturing in the well 2099, AHPP presence etc. which are apparently related to the destruction zones. Based on B.M. Valayev and P.N. Kropotkin's of Deep Earth degassing theory, this "pipes" of depth degassing [7], according to R.M. Bembel and co-authors are geosolitons [6], etc.

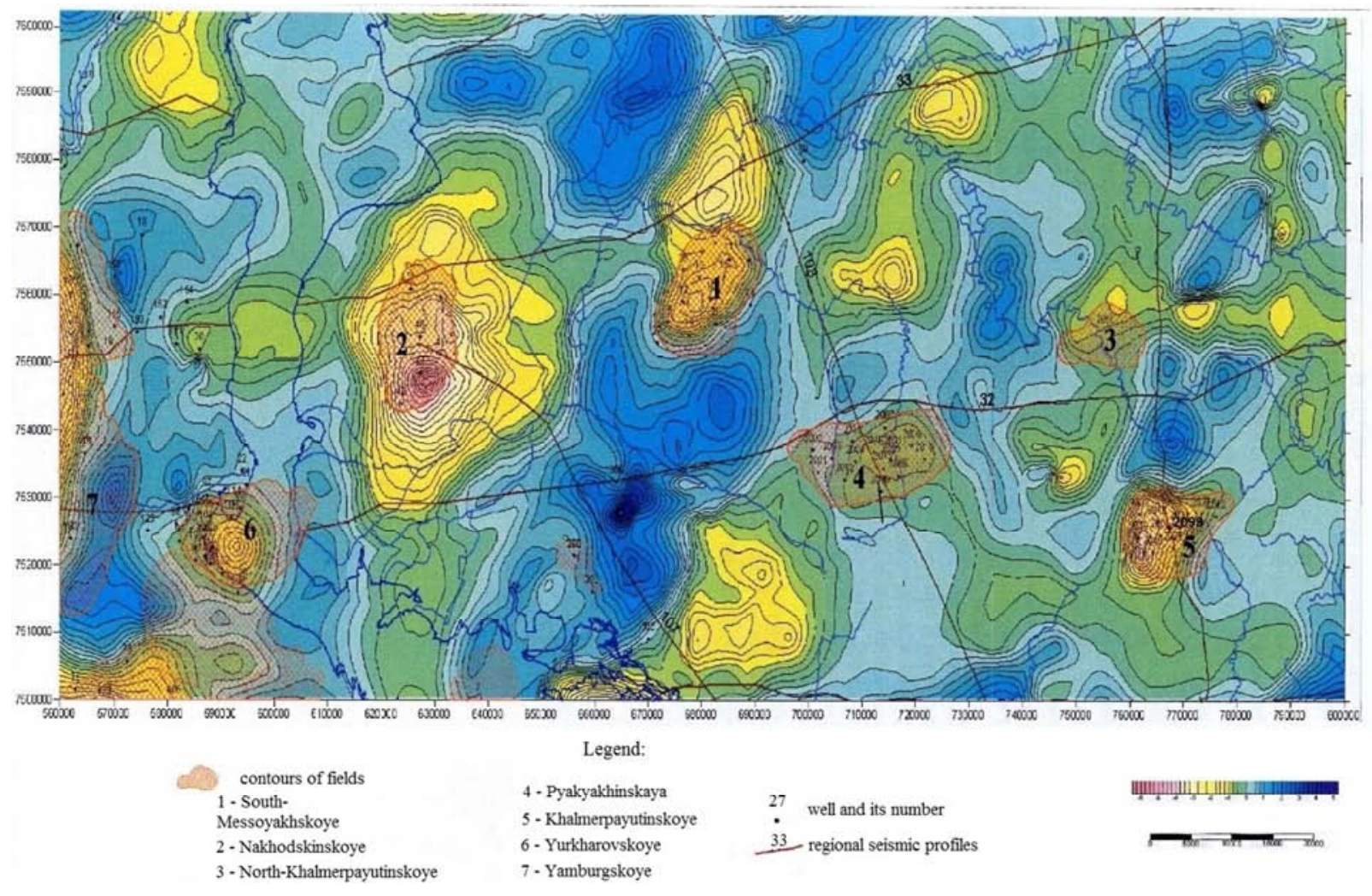

Figure 5. Map of local gravity anomalies within the Bolshekhetskaya depression in the North of Western Siberia.

If there are traps in these zones in the Achimov strata, they should be filled with hydrocarbons with the formation of deposits with AHPP. Upper Achimov's clays are a regional fluid seal, therefore, in the overlying layer of group B, the AHPP is usually absent. 


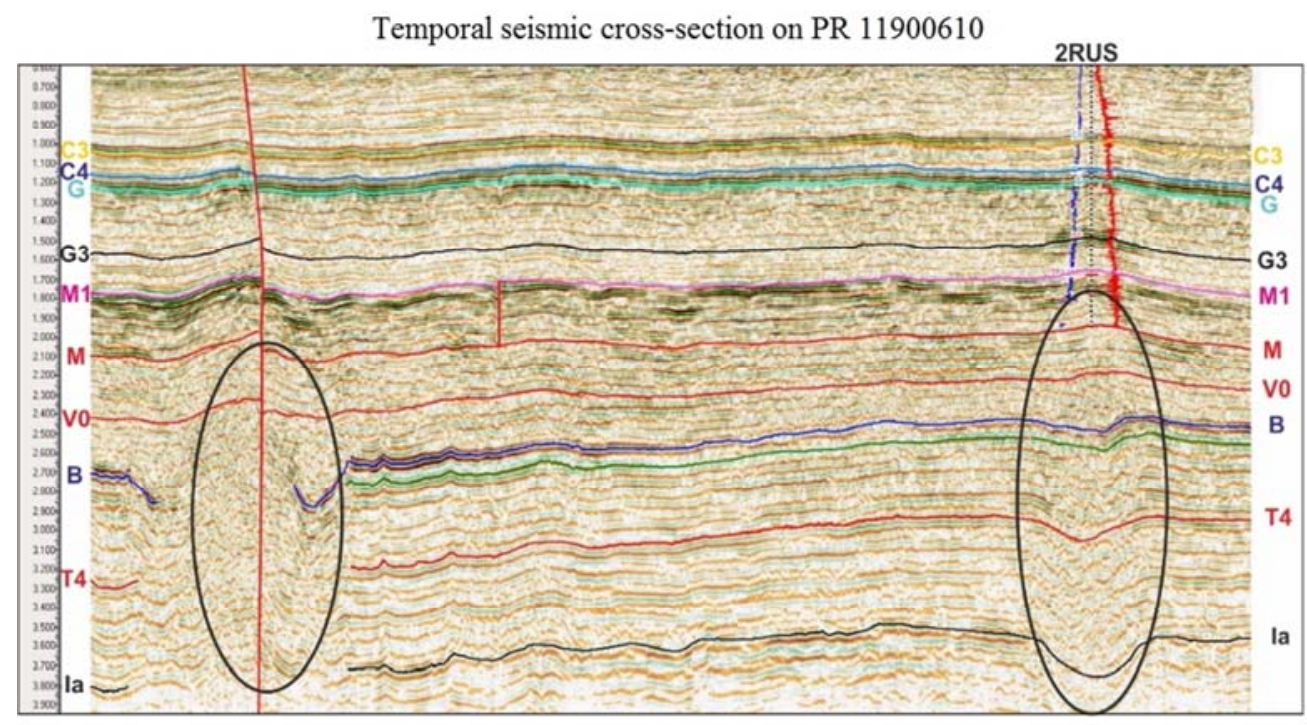

Figure 6. Inverted ring structure within the Rusanovsky uplift of the Kara Sea.

Within the offshore part of the Kara Sea (South Kara Syneclise [2-3]), the IRS series is also detected in Rusanovskaya (Figure 6), Petrovskaya (Figure 7) and other uplifts.

Firstaev E.N. and others authors (2015) call them "false" inversion structures and associate them with the heterogeneity of pore pressure and its influence on the velocity characteristics of local seismic waves. When identifying the local speed anomalies, the authors used the temporary thickness maps. Maps build by modeling a low-frequency trend. Both positive increments - classical, and negative increments are identified. The Petrovskaya structure is an example of a negative increment.

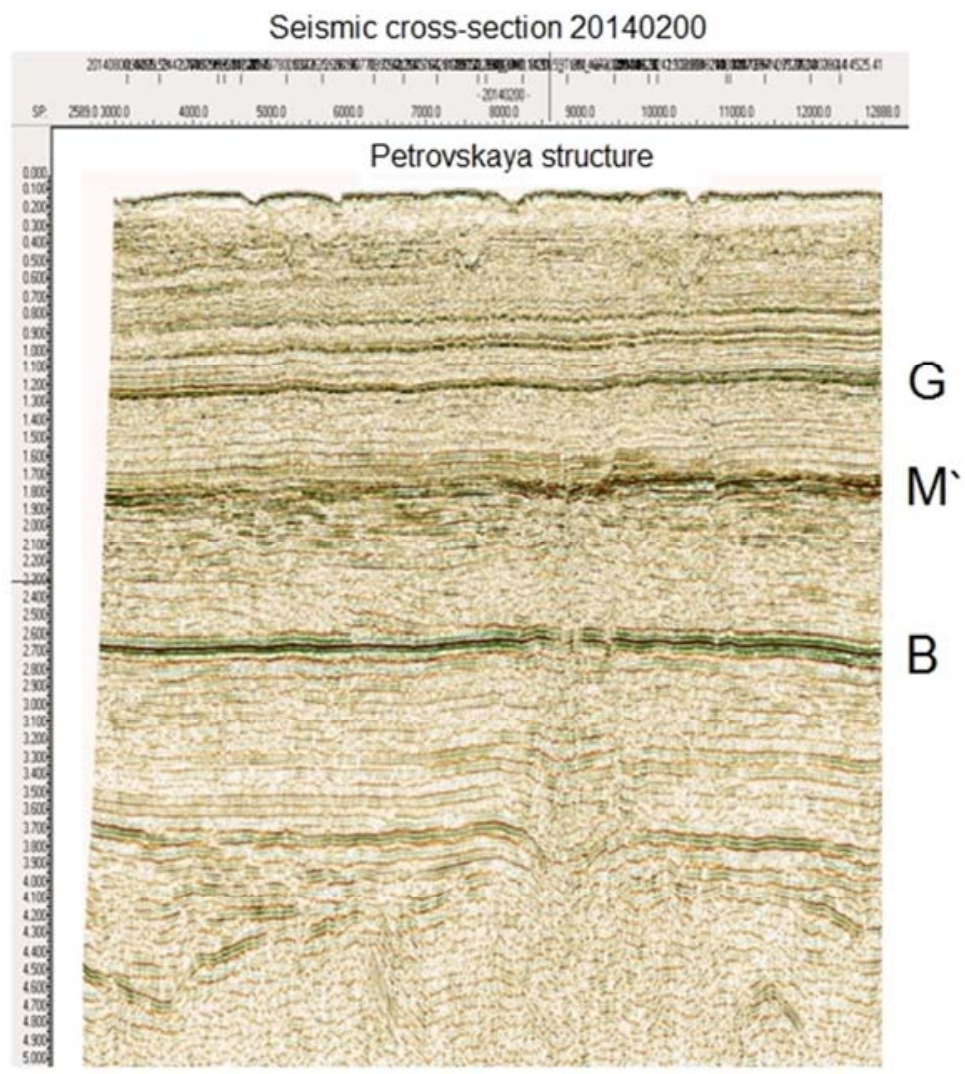

Figure 7. Characteristics of the wave pattern within the Petrovskaya uplift of the Kara Sea.

For explanation the variety of occurrence on time sections velocity abnormals (Figure 8 ) the evolution range of anomaly formation from formation to discharge presence as compression - decompression - dissipation.
Ring-shaped forms are identified well on the axonometric perspective of the structural map along the reflection horizon G (Figure 9). 


\section{Conclusions}

Thus, despite the diversity of ideas on the geological nature of IRS, their presence, in author's opinion, on the one hand should be considered as the indicator of AHPP

\section{Classical anomaly (example of compression) Overpressure formation}

prognosis areas (Figure 1), which is very important when drilling wells, especially in the Kara Sea shelf. On the other hand, generally, in their development zones a significant hydrocarbon potential floor has been identified, which is a positive criterion for oil- and gas-bearing range.
Discharge. Dissipation. Pressure conditions are leveled and are System of tectonic disturbances is formed hydrostatic
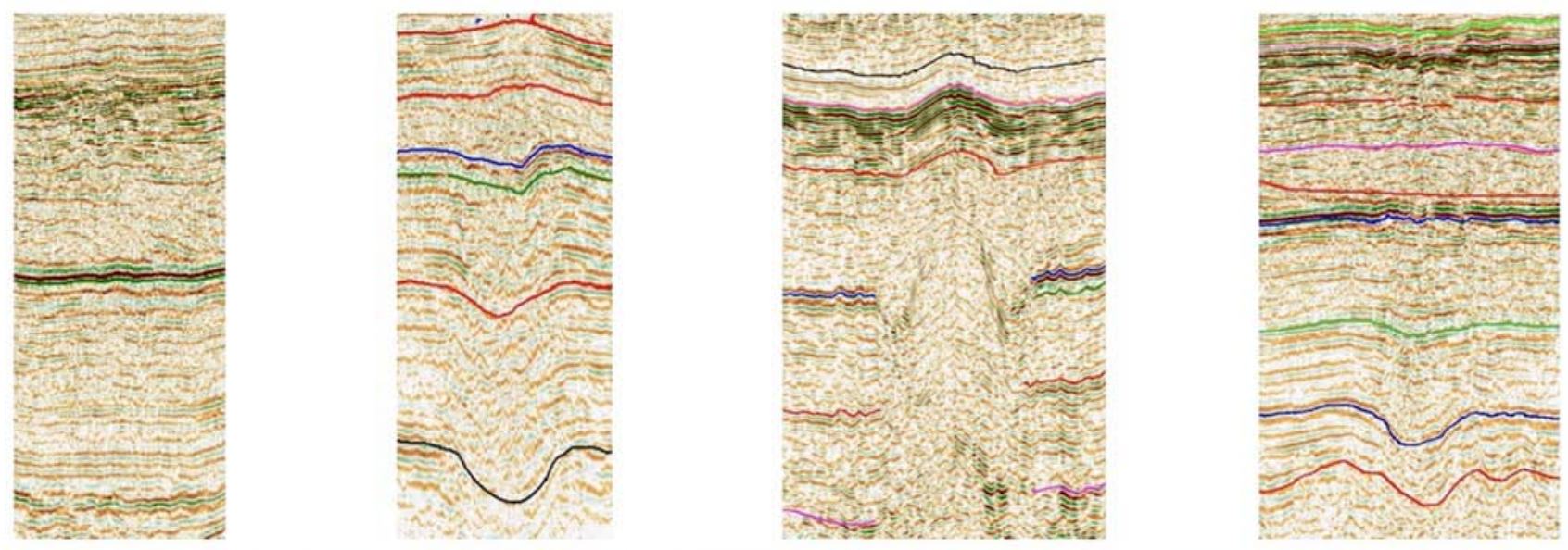

Figure 8. Theoretical scheme of the evolution of overpressure from formation to discharge.

The axonometry of the structural map along the reflecting horizon $\mathrm{G}$
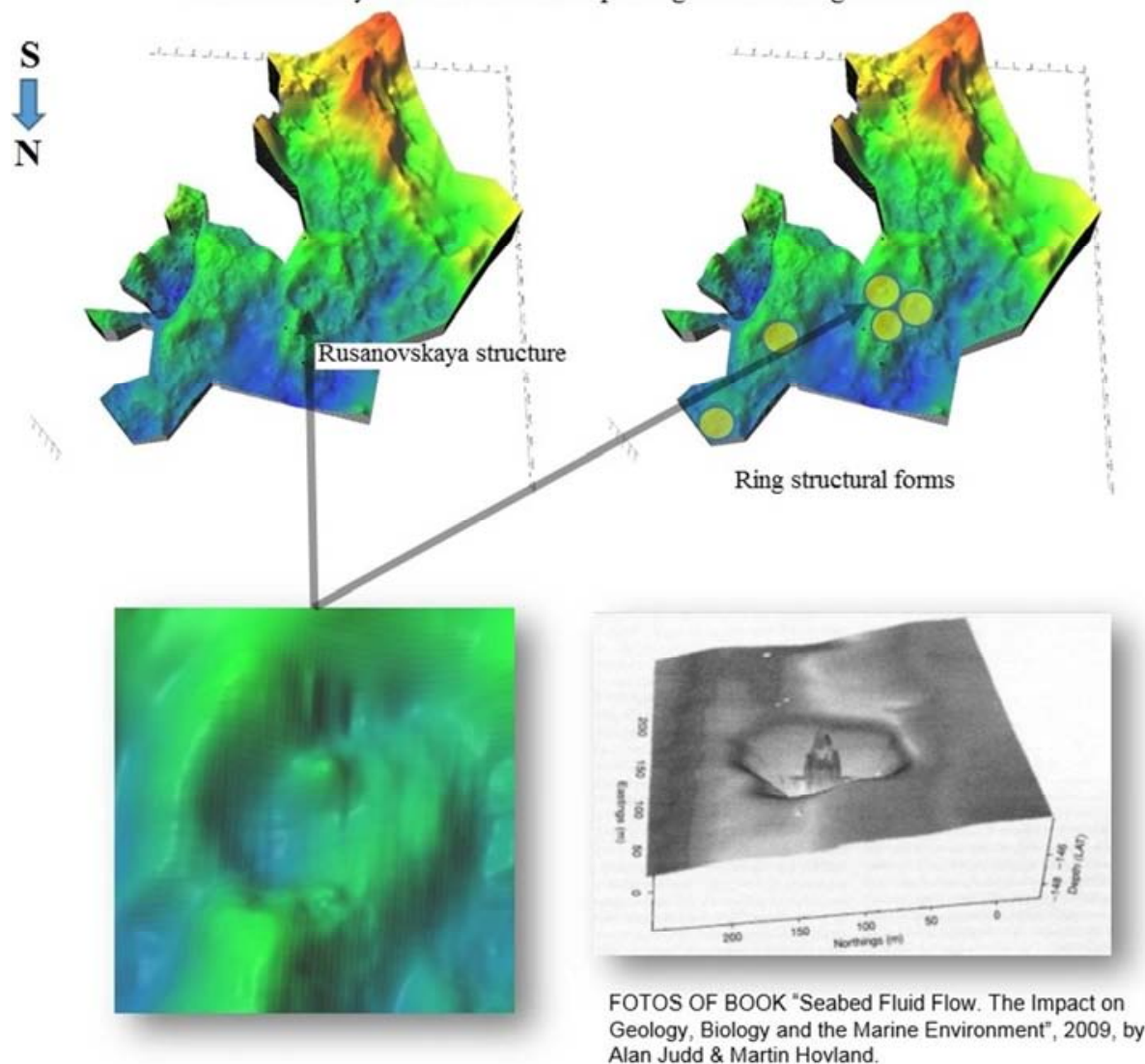

FOTOS OF BOOK "Seabed Fluid Flow. The Impact on Geology, Biology and the Marine Environment", 2009, by Alan Judd \& Martin Hovland.

Figure 9. The identification of ring-shaped forms on the structural map of the Reflection horizon $G$. 


\section{References}

[1] Borodkin V. N. Methodological aspects of local petroleum potential prediction. // Mountain sheets, Tyumen, 2006, № 1, p. 4-9.

[2] Refinement of the neocom seismic facies complexes in the Kara Sea. / V.N. Borodkin, A.R. Kurchikov, A. S. Nedosekin [et al.] // Geology, geophysics and development of oil and gas fields. M: OJSC "VNIIOENG", 2015, No. 11, p. 14-24.

[3] Estimation of the prospects for the oil and gas potential of the Kara Sea area based on 2D seismic survey data. / V. N. Borodkin, A. R. Kurchikov, A. S. Nedosekin [et al.] // Geomodel-2016, EAGE, Gelendzhik, 2016, p. 58-64.

[4] Adiev Ya. R., Gataulin R. M. Ring structures - "gas pipes" of the north of Western Siberia. // Geophysics. Special Issue "Bashgeofizika", 2003, p. 15-23.

[5] Balanok I. E., Sorokhtin O. G. On the connection of petroleum potential with island-type volcanic belts. (Rep. Interved. Sat. Scientific. Tr. AN USSR / Institute of Geology and Geochemistry of combustible minerals. Issue 60: Geology and geochemistry of minerals). Lvov: Science Dumka, 1983, p. 38 .

[6] Bembel R. M., Megerya V. M., Bembel S. R. Geosolitons and degassing of the Earth // Degassing of the Earth: geodynamics, geofluids, oil and gas; Materials international conference M.: GEOS, 2002, p. 95-97.

[7] Valyaev B. M., Kropotkin P. N. Zonality of oil and gas accumulation and deep hydrocarbon degassing in sedimentary basins (due to their geodynamic evolution) // Geodynamic evolution of sedimentary basins: Tez. report International Symposium. M., 1992, p. 34.
[8] Girshgorn L.Sh. Disharmonic uplifts in the sedimentary cover of the north of the West Siberian Plate. // Soviet geology. 1987, No. 4, p. 5-13.

[9] Borodkin V. N., Nezhdanov A. A. Abnormal reservoir pressure in deposits of various types of Mesozoic of Western Siberia // Tr. ZapSibNIGNI, Vol. 144, 1979, p. 21-29.

[10] V. N. Borodkin, A. R. Kurchikov. On the question of clarification of the western and eastern borders of the Achimov clinoform complex of Western Siberia. // Geology and Geophysics, Novosibirsk, Publishing House of the Siberian Branch of the Russian Academy of Sciences, 2015, No. 9, Vol. 56, p. 1630-1642.

[11] Karogodin Yu. N., Klimov S. V., Khramov M. R. Regional stratons - Callovian-Upper Jurassic section of Western Siberia (system-litmological rocks) // Jurassic System of Russia: Problems of Stratigraphy and Paleogeography / Ed. V. A. Zakharov, Saratov, Nedra, 2009, p. 83-85.

[12] Kashtanov V. A. Local oil forecast based on aeromagnetic survey data. // Geology of oil and gas, 1988, № 12, p. 7-12.

[13] Pavlov D. I. Exogenous chloride waters and endogenous ore formation. M.: Nedra, 1975, 224 p.

[14] Gurari F. G. Domanikites and their petroleum potential. // Soviet Geology, 1981, No. 11, p. 3-12.

[15] Ivankin P. F., Nazarova N. I. Deep fluidization of the Earth's crust and its role in petro-urogenesis, salt and oil formation. M.: TsNIGRN, 2001, 208 p.

[16] Ivankin P. F., Inikin P.V. About the relationship of carbon and water in petrogenesis. // Soviet Geology, 1977, No. 1, p. 3546.

[17] Kropotkin P. N. Degassing of the Earth and the genesis of hydrocarbons. // Journal of All Union Chemical Society named after Mendeleev - 1986, vol. XXXI, No. 5, p. 540-547. 